\title{
Pulmonary megakaryocytes: "missing link" between cardiovascular and respiratory disease?
}

\author{
G K SHARMA, I C TALBOT \\ From the Department of Pathology, University of Leicester, Leicester Royal Infirmary
}

SUMMARY Pulmonary megakaryocytes were quantitated in a series of 30 consecutive hospital necropsies using a two stage immunoperoxidase stain for factor VIII related antigen. In all 30 cases they were found with a mean density of 14.65 megakaryocytes $/ \mathrm{cm}^{2}$ in lung sections of $5 \mu \mathrm{m}$ in thickness. The maximum concentration of intrapulmonary megakaryocytes was consistently found to be in the central zone of the right upper lobe. Less than $22 \%$ of the observed cells possessed abundant cytoplasm, the rest appearing as effete, naked, and seminaked nuclei. The mean megakaryocyte count was found to be increased in association with both respiratory pathology (positive smoking history and impaired lung function) and cardiovascular disease states-shock; thromboembolism; myocardial infarction; and severe atheroma in the abdominal aorta, the coronary circulation, and the circle of Willis. Pulmonary megakaryocytes probably embolise from bone marrow. This may reflect stimulated thrombopoiesis, caused by increased platelet consumption in association with atherosclerotic disease, but it cannot be taken to confirm that the lung is the principal site of platelet production.

The megakaryocyte is now firmly established as the source of all platelets, but the exact site and mechanisms of platelet production and release remain in doubt. ${ }^{1}$ It is widely accepted that nascent platelets are delineated within the megakaryocyte cytoplasm by a demarcation membrane system ${ }^{2}$ which forms by invagination of the plasmalemma. ${ }^{3}$ This provides the lines of cleavage and will ultimately form the platelet plasma membrane. The actual release of platelets into the circulation is explained by the "pseudopodial theory"4-8 which proposes that a megakaryocyte produces about six elongated cytoplasmic pseudopodia, each with a core of platelet organelles. These pro-platelets penetrate the vascular sinusoids via the transendothelial route and, after being pinched off into the bloodstream, eventually fragment to yield about 1000 platelets. Recently, however, it was suggested that all platelet production occurs in the pulmonary microvasculature by the physical fragmentation of megakaryocyte emboli ${ }^{910}$ and considerable evidence supports this theory:

1 The migration of intact megakaryocytes across the marrow-blood barrier has been confirmed by both static ultrastructural ${ }^{911}$ and dynamic microcinematographic studies. ${ }^{12}$

Accepted for publication 9 April 1986
2 Intact megakaryocytes are now known to be normal constituents of blood. ${ }^{13}$

3 Intrapulmonary megakaryocytes are a consistent finding at necropsy, ${ }^{14}$ especially in disease states ${ }^{15}$ and, despite early conflict of opinion, ${ }^{1617}$ vascular rearrangement experiments have proved that they do not arise de novo but are brought to the lungs by the venous blood. ${ }^{18}$

4 The lungs serve as a filter for circulating megakaryocytes because there is a reduction in both the number and size of megakaryocytes as blood flows through the pulmonary microcirculation. ${ }^{19-24}$

5 Platelet production in the lungs is indicated by higher platelet counts in central arterial blood than in central venous blood. ${ }^{162223}$

The above evidence indicates that pulmonary megakaryocytes are emboli from the marrow, which, due to their large size, are retained and fragmented in the intrapulmonary capillaries to yield platelets. Agreement has not been reached, however, on the extent of their contribution to the total platelet population, with values from $7 \%{ }^{25}$ to almost $100 \%{ }^{21}$ being reported. Recently, the platelet volume distribution, as measured by particle sizing, was shown to be log normal rather than the Gaussian distribution usually shown by mitotic cells. ${ }^{26}$ It has been suggested that this unique volume distribution can be 
explained only if all platelet production occurs in the lungs by a process of physical fragmentation, probably as a result of sequential random binary divisions at the pulmonary bifurcations. ${ }^{91026}$ If this is the case then disturbance of pulmonary-megakaryocyte interaction may cause dysthrombopoiesis, ${ }^{27}$ which, in turn, may explain the common coexistence of cardiovascular and respiratory disease. ${ }^{28-30}$

This study aimed to explore these possibilities by investigating the incidence, concentration, distribution, and morphology of pulmonary megakaryocytes in a series of hospital necropsies and relating the findings to respiratory and atherothrombotic disorders.

\section{Material and methods}

A block of tissue $1-2 \mathrm{~cm}^{2} \times 0.5 \mathrm{~cm}$ was collected from the centre and periphery of each of the four main lung lobes during 30 consecutive unselected hospital post mortem examinations at the Leicester Royal Infirmary. Care was taken to avoid areas with large airways or obvious evidence of disease. After overnight fixation in $5 \%$ formol/acetic acid $(5 \%$ glacial acetic acid in 4\% neutral phosphate buffered formaldehyde solution) the tissue was paraffin processed and cut into $5 \mu \mathrm{m}$ sections. These were then stained for factor VIII related antigen, using an indirect immunoperoxidase technique, as described by Crocker and Smith. ${ }^{31}$ Factor VIII related antigen is found on the platelet membrane, ${ }^{32}$ some of it being adsorbed on to receptors from the plasma but a high proportion being an integral part of the platelet membrane and originating from the demarcation membrane system. ${ }^{33}$

The area of each section was determined by planimetry using a Kontron Videoplan with graphic tablet before screening for megakaryocytes with a Leitz SMLux microscope, using the $\times \mathbf{4 0}$ objective; all suspect cells were examined under oil immersion, using the $\times 100$ objective. Megakaryocytes were categorised into three types: intact nuclei; seminaked nuclei; and naked nuclei (fig 1). A fourth category, the "possible", or "?" megakaryocyte, was also used to include cells satisfying some but not all the criteria needed for the above three forms. Cells resembling

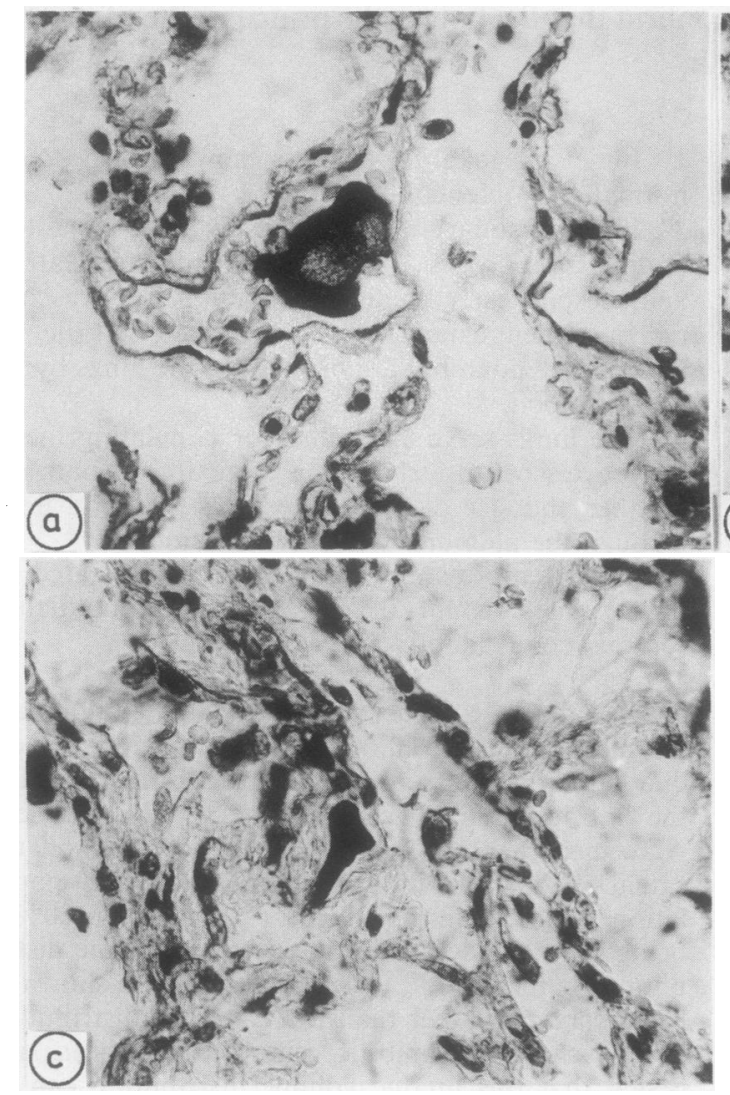

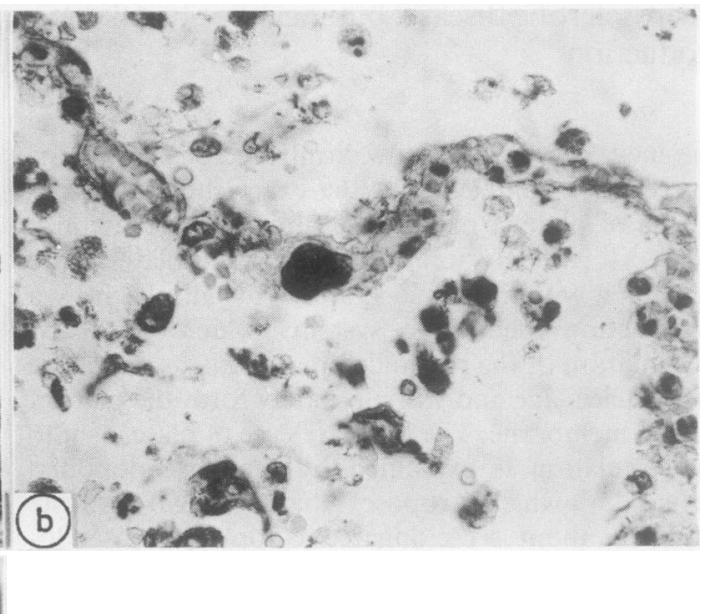

Fig 1 Morphology of intrapulmonary megakaryocytes.

Fig 1a Intact megakaryocyte is large intravascular cell with large multilobed hyperchromatic nucleus enclosed by abundant positively staining cytoplasm.

Fig 1b Seminaked megakaryocyte nucleus is similar but smaller due to loss of cytoplasm.

Fig lc Naked megakaryocyte nucleus is large intensely staining nucleus, totally denuded of cytoplasm, and moulded into shape of enclosing vascular channel.

(DAB staining of peroxidase-antiperoxidase preparations.) All magnifications $\times 320$. 
Table 1 Intrapulmonary distribution of megakaryocytes (mean values for 30 subjects)

\begin{tabular}{|c|c|c|c|c|c|c|}
\hline \multicolumn{2}{|c|}{ Site of tissue sampling } & \multicolumn{2}{|c|}{ No of megakaryocytes $/ \mathrm{cm}^{2}$} & \multirow{2}{*}{$\begin{array}{l}\text { Absolute difference } \\
(1-2)\end{array}$} & \multirow{2}{*}{$\left(\frac{1-2}{1-2} \times 100\right)$} & \multirow[b]{2}{*}{$p$ value } \\
\hline 1 & 2 & $l$ & 2 & & & \\
\hline $\begin{array}{l}\text { Right lung } \\
\text { Upper lobes } \\
\text { Central zones }\end{array}$ & $\begin{array}{l}\text { Left lung } \\
\text { Lower lobes } \\
\text { Peripheral zones }\end{array}$ & $\begin{array}{l}15.58 \\
15.67 \\
16.41\end{array}$ & $\begin{array}{l}13.69 \\
14.34 \\
14.57\end{array}$ & $\begin{array}{l}1.89 \\
1.33 \\
1.84\end{array}$ & $\begin{array}{l}8 \cdot 27 \\
6 \cdot 37 \\
6 \cdot 66\end{array}$ & $\begin{array}{l}p<0.001 \\
p<0.005 \\
p<0.0005\end{array}$ \\
\hline
\end{tabular}

megakaryocytes were occasionally seen in the extravascular spaces. These could be either true megakaryocytes or large alveolar macrophages and so were included in the "?" category. After attending the necropsy and studying the clinical case notes three sets of clinicopathological data were recorded.

\section{RESPIRATORY SYSTEM}

The subjects were divided into smokers and nonsmokers, and pulmonary performance was classified as normal or impaired according to the clinical history, physical signs, and lung function tests (if performed).

\section{CARDIOVASCULAR SYSTEM}

Shock Shock was diagnosed from a clinical description of pallor, sweating, tachycardia, and hypotension $(100 / 70 \mathrm{~mm} \mathrm{Hg}$ being taken as an arbitrary lower limit for the normal blood pressure) at some stage during the week before death.

Thromboembolism The presence or absence of thromboembolic disease was determined solely from the necropsy findings.

Myocardial infarction Infarcts found at necropsy were described as being small (less than $1 \mathrm{~cm}^{2}$ ), medium (1-3 cm $\mathrm{cm}^{2}$ ), or large (greater than $3 \mathrm{~cm}^{2}$ or transmural).

Table 2 Pulmonary megakaryocyte counts related to various clinicopathological data

\begin{tabular}{|c|c|c|c|c|c|c|c|}
\hline \multirow{2}{*}{\multicolumn{2}{|c|}{ Clinicopathological information }} & & \multirow[b]{2}{*}{ No of subjects } & \multicolumn{3}{|c|}{ Megakaryocytes $/ \mathrm{cm}^{2}$ in sections of lung } & \multirow[b]{2}{*}{$p$ value } \\
\hline & & & & Mean & Range & $\begin{array}{l}\text { Standard } \\
\text { deviation }\end{array}$ & \\
\hline \multirow{3}{*}{$\begin{array}{l}\text { Respiratory } \\
\text { system }\end{array}$} & {$\left[\begin{array}{r}\text { Smoking } \\
\text { history }\end{array}\right.$} & $\begin{array}{l}\text { Non-smoker } \\
\text { Smoker }\end{array}$ & $\begin{array}{l}14 \\
13\end{array}$ & $\begin{array}{l}12 \cdot 96 \\
18 \cdot 04\end{array}$ & $\begin{array}{l}3 \cdot 59-36 \cdot 71 \\
1 \cdot 71-29.66\end{array}$ & $\begin{array}{l}7 \cdot 39 \\
7 \cdot 15\end{array}$ & $p=0.03$ \\
\hline & $\underset{\text { function }}{\text { Lung }}$ & $\begin{array}{l}\text { Normal } \\
\text { Impaired }\end{array}$ & $\begin{array}{r}7 \\
22\end{array}$ & $\begin{array}{l}13 \cdot 53 \\
15 \cdot 57\end{array}$ & $\begin{array}{l}1 \cdot 71-21 \cdot 00 \\
3 \cdot 59-36 \cdot 71\end{array}$ & $\begin{array}{l}6 \cdot 23 \\
7 \cdot 90\end{array}$ & $p>0.1$ \\
\hline & Shock & $\begin{array}{l}\text { Absent } \\
\text { Present }\end{array}$ & $\begin{array}{r}23 \\
7\end{array}$ & $\begin{array}{l}12 \cdot 97 \\
20 \cdot 12\end{array}$ & $\begin{array}{r}1 \cdot 71-29 \cdot 66 \\
12 \cdot 15-36 \cdot 71\end{array}$ & $\begin{array}{l}7 \cdot 17 \\
7 \cdot 40\end{array}$ & $p=0.02$ \\
\hline \multirow[t]{5}{*}{$\begin{array}{l}\text { Cardiovascular } \\
\text { system }\end{array}$} & $\begin{array}{c}\text { Thromboembolic } \\
\text { disease }\end{array}$ & $\begin{array}{l}\text { Absent } \\
\text { Present }\end{array}$ & $\begin{array}{l}16 \\
14\end{array}$ & $\begin{array}{l}13 \cdot 22 \\
16 \cdot 25\end{array}$ & $\begin{array}{l}1 \cdot 71-29 \cdot 66 \\
3 \cdot 78-36 \cdot 71\end{array}$ & $\begin{array}{l}7 \cdot 65 \\
7 \cdot 72\end{array}$ & $p>0.1$ \\
\hline & $\begin{array}{l}\text { Myocardial } \\
\text { infarction }\end{array}$ & $\begin{array}{l}\text { Absent } \\
\text { Small } \\
\text { Medium } \\
\text { Large }\end{array}$ & $\begin{array}{r}23 \\
1 \\
1 \\
3\end{array}$ & $\begin{array}{l}13 \cdot 24 \\
36 \cdot 71 \\
18 \cdot 20 \\
16 \cdot 35\end{array}$ & $1 \cdot 71-29 \cdot 66$ & $7 \cdot 00$ & $p=0.025$ \\
\hline & {$[\operatorname{Sex}$} & $\begin{array}{l}\text { Male } \\
\text { Female }\end{array}$ & $\begin{array}{r}21 \\
9\end{array}$ & $\begin{array}{l}14 \cdot 96 \\
12 \cdot 33\end{array}$ & $\begin{array}{l}4 \cdot 01-29 \cdot 66 \\
1 \cdot 71-36 \cdot 71\end{array}$ & $\begin{array}{r}6.53 \\
10 \cdot 90\end{array}$ & $p>0 \cdot 1$ \\
\hline & Infection & $\begin{array}{l}\text { Absent } \\
\text { Present } \\
\text { Blood-borne }\end{array}$ & $\begin{array}{r}15 \\
12 \\
3\end{array}$ & $\begin{array}{l}15 \cdot 00 \\
13 \cdot 93 \\
15 \cdot 60\end{array}$ & $\begin{array}{r}1 \cdot 71-36 \cdot 71 \\
4 \cdot 01-29 \cdot 66 \\
13 \cdot 17-19 \cdot 53\end{array}$ & $\begin{array}{l}8 \cdot 85 \\
7 \cdot 25 \\
2 \cdot 81\end{array}$ & $\begin{array}{l}p>0.1 \\
p>0.1\end{array}$ \\
\hline & Malignancy & $\begin{array}{l}\text { Absent } \\
\text { Present } \\
\text { Metastatic }\end{array}$ & $\begin{array}{r}16 \\
6 \\
8\end{array}$ & $\begin{array}{l}15 \cdot 80 \\
12 \cdot 29 \\
14 \cdot 07\end{array}$ & $\begin{array}{l}1 \cdot 71-36 \cdot 71 \\
3 \cdot 78-23 \cdot 32 \\
6 \cdot 95-19 \cdot 53\end{array}$ & $\begin{array}{l}8 \cdot 96 \\
7 \cdot 64 \\
4 \cdot 30\end{array}$ & $\begin{array}{l}p>0.1 \\
p<0.1\end{array}$ \\
\hline \multirow[t]{5}{*}{$\begin{array}{l}\text { Miscellaneous } \\
\text { data }\end{array}$} & Haemoglobin & $\begin{array}{l}\text { Normal } \\
M=16 \pm 2 \mathrm{~g} / \mathrm{dl} \\
F=14 \pm 2 \mathrm{~g} / \mathrm{dl}\end{array}$ & 12 & $17 \cdot 01$ & $3 \cdot 59-36 \cdot 71$ & $9 \cdot 42$ & \\
\hline & & Low & 16 & $14 \cdot 35$ & $4 \cdot 01-22 \cdot 46$ & $5 \cdot 83$ & $p>0.1$ \\
\hline & $\begin{array}{l}\text { White } \\
\text { cell } \\
\text { count }\end{array}$ & $\begin{array}{l}\text { Normal } \\
7 \pm 3 \times 10^{9} / 1 \\
\text { High }\end{array}$ & $\begin{array}{r}7 \\
20\end{array}$ & $\begin{array}{l}20 \cdot 38 \\
14 \cdot 01\end{array}$ & $\begin{array}{r}14 \cdot 72-36 \cdot 71 \\
3 \cdot 95-29 \cdot 66\end{array}$ & $7 \cdot 53$ & $\mathrm{p}<0.05$ \\
\hline & $\begin{array}{l}\text { Platelet } \\
\text { count }\end{array}$ & $\begin{array}{l}\text { Normal } \\
290 \pm 150 \times 10^{9} / 1 \\
\text { Low } \\
\text { High }\end{array}$ & $\begin{array}{r}17 \\
4 \\
7\end{array}$ & $\begin{array}{l}16.98 \\
11.98 \\
13.85\end{array}$ & $\begin{array}{l}3 \cdot 59-36 \cdot 71 \\
\\
6 \cdot 95-22 \cdot 19 \\
4 \cdot 01-22 \cdot 46\end{array}$ & $\begin{array}{l}8 \cdot 19 \\
6 \cdot 99 \\
5 \cdot 91\end{array}$ & $\begin{array}{l}p>0.1 \\
p>0.1\end{array}$ \\
\hline & Fever & $\begin{array}{l}\text { Absent } \\
\text { Present }\end{array}$ & $\begin{array}{l}12 \\
17\end{array}$ & $\begin{array}{l}16 \cdot 84 \\
14 \cdot 27\end{array}$ & $\begin{array}{l}3 \cdot 59-36 \cdot 71 \\
4 \cdot 01-29 \cdot 66\end{array}$ & $\begin{array}{l}8 \cdot 62 \\
7 \cdot 02\end{array}$ & $p>0.1$ \\
\hline
\end{tabular}




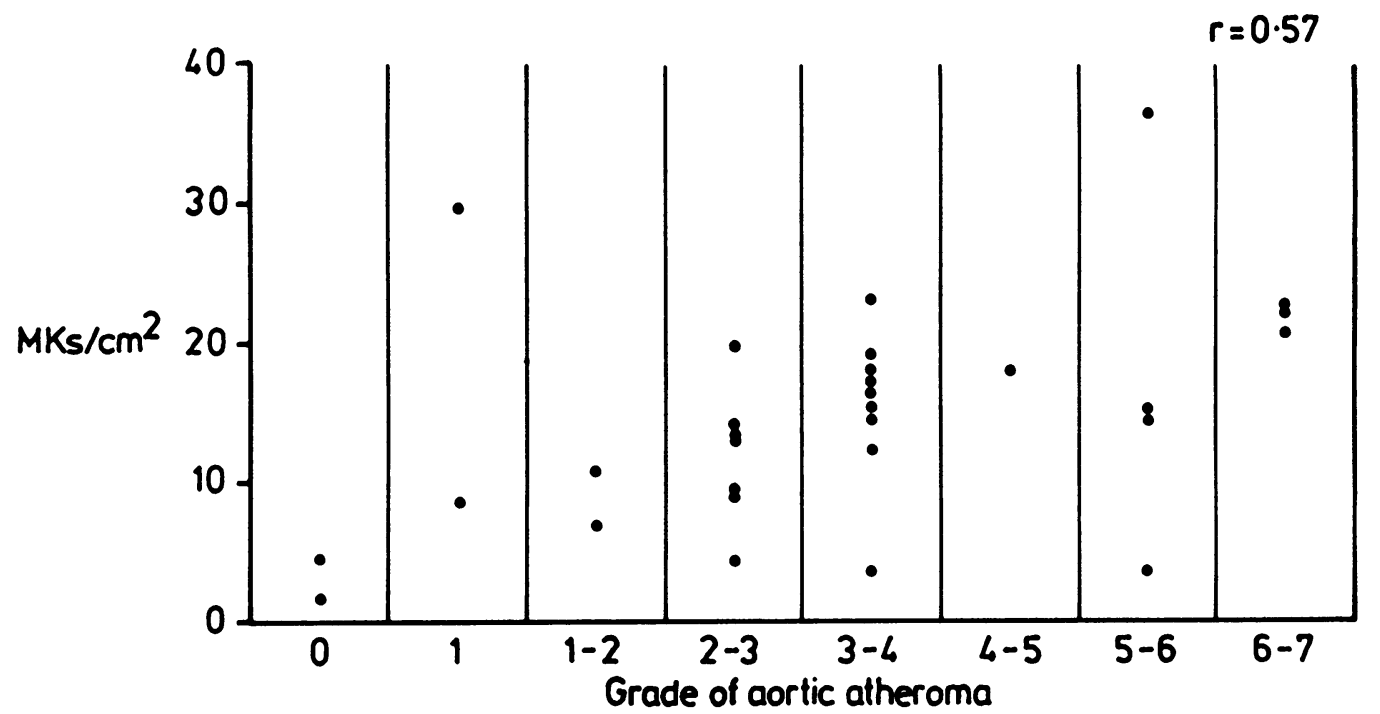

$\begin{array}{ccccccccr}\text { Mean } & 2.86 & 18.86 & 8.4 & 11.85 & 15.66 & 18.01 & 17.61 & 21.88 \\ \text { (SD) } & 1.15 & 10.80 & 1.88 & 4.40 & 5.13 & 0 & 11.99 & 0.63\end{array}$

Fig 2 Pulmonary megakaryocyte counts and aortic atheroma

Aortic atheroma The abdominal aorta was opened longitudinally and atheromatous severity was assessed, as described by McGill et $a{ }^{34}{ }^{34}$ by comparing it with a panel of aortas graded 1-2 to 6-7 inclusive. Four of the 30 cases studied could not be satisfactorily equated with any of the six specimen aortas; two were designated as grade 1 atheroma while the other pair (both from newborn babies) were classified as grade 0 atheroma.

Coronary atheroma The main coronary arteries were cut transversely at regular intervals and the luminal diameter assessed. Four grades of atheromatous severity were recognised: absent or all main coronary vessels widely patent; mild, or minimal luminal narrowing of one of the major arteries; moderate or less than $50 \%$ luminal reduction of one or more of the major coronary arteries; severe, or greater than $50 \%$ reduction of the luminal diameter of all three main coronary arteries.

Cerebral atheroma Atherosclerotic disease in the circle of Willis was absent (widely patent), mild (noticeable luminal reduction), or severe (lumen more than $50 \%$ occluded).

\section{MISCELLANEOUS VALUES}

The following miscellaneous clinicopathological data were also recorded: sex, age, infection (absent, present, or blood borne), malignancy (absent, present, or metastatic), and the antemortem haemoglobin, white cell count, platelet count, and body temperature.

\section{Results}

THE INCIDENCE AND CONCENTRATION OF PULMONARY MEGAKARYOCYTES

Megakaryocytes were found in the lungs of all 30 nec ropsy specimens studied, but their concentration was variable, ranging from only 2 megakaryocytes $/ \mathrm{cm}^{2}$ to as many as 37 megakaryocytes $/ \mathrm{cm}^{2}$ (mean 14.65 megakaryocytes $/ \mathrm{cm}^{2}$ ).

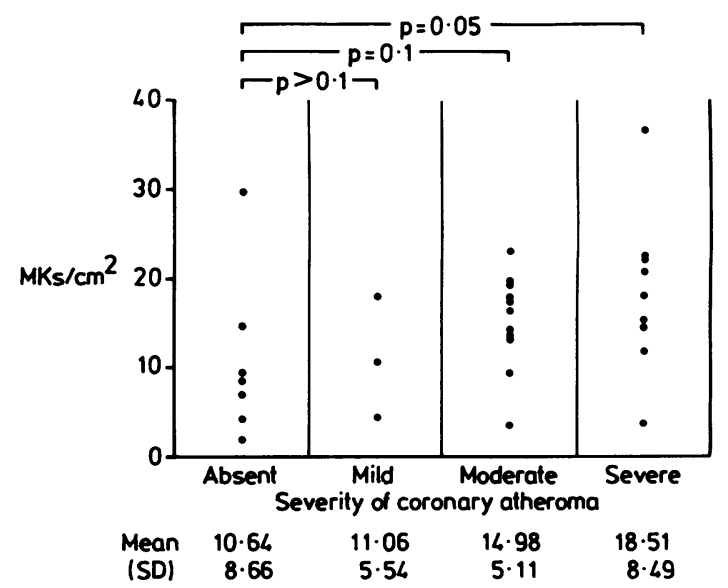

Fig 3 Pulmonary megakaryocyte counts and coronary atheroma. 


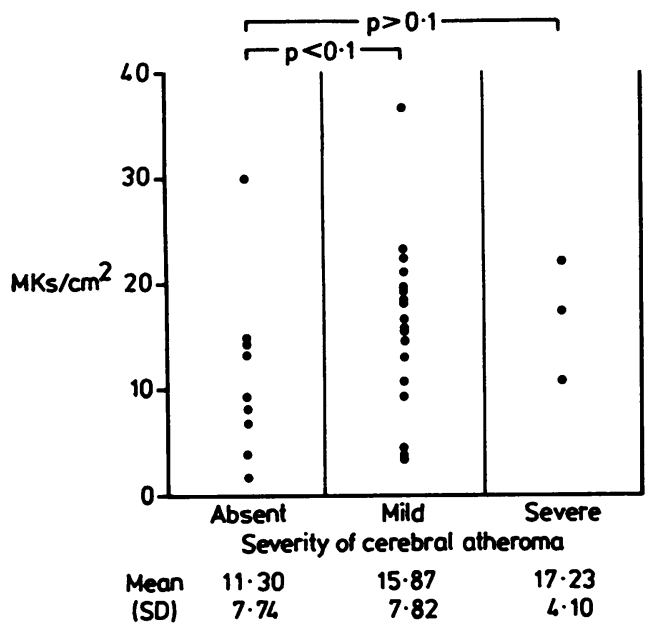

Fig 4 Pulmonary megakaryocyte counts and cerebral atheroma.

\section{THE INTRAPULMONARY DISTRIBUTION OF MEGAKAR YOCYTES}

Table 1 shows that there is a higher concentration of megakaryocytes in the right lung than in the left, in the upper lobes than in the lower lobes, and in the central zones than in the periphery.

\section{THE MORPHOLOGY OF PULMONARY}

\section{MEGAKAR YOCYTES}

In all parts of the lungs only $22 \%$ of megakaryocytes were intact, with copious cytoplasm. Thirty one per cent were seminaked nuclei, $31 \%$ were naked nuclei, and the remaining $16 \%$ were classed "?".

\section{PULMONARY MEGAKARYOCYTES AND}

\section{CLINICOPATHOLOGICAL RELATIONS}

Respiratory system Pulmonary megakaryocytes were slightly increased in association with both a positive smoking history and impaired respiratory function, though significance was reached only in the case of a positive smoking history (table 2).

Cardiovascular system There was a significant increase in the pulmonary megakaryocyte count in association with shock, myocardial infarction, and severe atheroma in the abdominal aorta, coronary circulation, and the cerebral vessels. The increase in pulmonary megakaryocytes in thromboembolic disease was only slight (table 2 and figs 2,3 , and 4).

Miscellaneous clinicopathological data The pulmonary megakaryocyte count was significantly higher in relation to leucocytosis and slightly higher in men than in women, but there was no obvious association with age, infection, neoplasia, haemoglobin concentration, platelet count, or fever (table 2).

\section{Discussion}

The incidence of pulmonary megakaryocytes was $100 \%$, thereby supporting the results of previous work. ${ }^{14}$ This seems to be correlated with the general condition of patients before they die. One other study reported pulmonary megakaryocytes in $95 \%$ of hospital necropsies but only $67 \%$ of forensic necropsies. ${ }^{35}$

The concentration of pulmonary megakaryocytes (14.65 megakaryocytes $/ \mathrm{cm}^{2}$ in $5 \mu \mathrm{m}$ sections) coincides closely with the results of Smith and Butcher, ${ }^{15}$ who counted 100 high power fields and reported mean values of 14.2 megakaryocytes $/ \mathrm{mm}^{3}$ for their hospital cases but only $5 \cdot 1$ megakaryocytes $/ \mathrm{mm}^{3}$ for their forensic series. Aabo et al, ${ }^{35}$ however, quote an average of 4 megakaryocytes $/ \mathrm{cm}^{2}$ in forensic necropsies and 37 megakaryocytes $/ \mathrm{cm}^{2}$ in hospital necropsies in $7 \mu \mathrm{m}$ lung sections and estimate the maximum density in normal lungs to be 18 megakaryocytes $/ \mathrm{cm}^{2}$.

More recently, a study of burns victims found less than 2 megakaryocytes $/ \mathrm{cm}^{2}$ in lung sections of unspecified thickness. ${ }^{36}$ There are two possible reasons for this variation in the reported concentration of pulmonary megakaryocytes. Firstly, the pulmonary megakaryocyte count may be greater in hospital deaths than in forensic cases ${ }^{1535}$ due to an effect of disease states such as acute infections, ${ }^{153537}$ leucocytosis, ${ }^{35}$ haemorrhage, ${ }^{35}$ postoperative states, ${ }^{3738}$ shock, ${ }^{35}$ and the adult respiratory distress syndrome. ${ }^{39}$ Consumptive coagulopathy is believed to be the common pathogenetic mechanism producing increased pulmonary megakaryocyte counts in these states. ${ }^{3540}$ Secondly, previous studies have relied entirely on morphology for the identification of megakaryocytes in sections stained with haematoxylin and eosin or periodic acid Schiff. Wells et $a^{36}$ explained their low pulmonary megakaryocyte counts by their use of more stringent criteria to define a megakaryocyte. In this respect our investigation more reliably indicates the intrapulmonary megakaryocyte density, because it not only uses an immunocytochemical stain to assist in identification, but it also clearly defines the morphological criteria needed to identify a megakaryocyte.

The distribution of megakaryocytes is not uniform, and there is an appreciably greater concentration of cells in the right lung than in the left. This contrasts with the results of previous work, ${ }^{41}$ and there is no obvious explanation. It could be a simple "pooling effect"; perhaps right handed subjects are more likely to lie on their right side. The right lung may receive a disproportionately greater share of the cardiac output, or, because of the phenomenon of "plasma skimming", the left pulmonary artery, which arises as an 
offshoot from the main trunk, may receive only dilute plasma. Unknown local factors may make megakaryocyte filtration more effective or fragmentation less efficient in the right lung, or both.

The upper lobes have a consistently greater megakaryocyte count than the lower lobes, thus supporting the conclusions of Bendix-Hansen et al, ${ }^{41}$ who explained this in terms of bed rest changing the pulmonary blood flow. Our observations also showed that pneumonic consolidation was mostly confined to the lower lobes while emphysematous changes were almost exclusive to the upper lobes.

Emphysema may either cause an actual increase in intrapulmonary megakaryocytes or simply facilitate their identification; the converse is true for pneumonia. These two factors may be interrelated as severe basal congestion tends to divert blood to the upper lobes.

Consistent with the findings of previous work, ${ }^{41}$ the central zones have a greater megakaryocyte count than the lung periphery. Again, differential blood flow is a likely explanation, although the greater degree of expansion and contraction undergone by peripheral lung tissue may also be important factors.

\section{PULMONARY MEGAKARYOCYTES AND \\ RESPIRATORY AND CARDIOVASCULAR \\ PATHOLOGY}

The common coexistence of pulmonary and atherothombotic disorders is well known ${ }^{4243}$ and cigarette smoking has been implicated in both chronic bronchitis and coronary artery disease. The causal factors in these disorders often coexist-cigarette smokers are more likely to consume a high fat diet-these being established risk factors in respiratory and cardiovascular pathology, respectively. When Friedman et $a l^{\mathbf{4 4}}$ failed to account for their observed association between diminished vital capacity and clinical coronary artery disease in terms of these accepted explanations, they suggested the existence of "some other connection between pulmonary function and the state of the coronary arteries or myocardium."

There are three such possibilities: firstly, chronic respiratory disease may cause hypoxia which increases aortic cholesterol accumulation, probably due to ischaemic endothelial injury ${ }^{45}$; secondly, lung disease may impair intrapulmonary production of prostacyclin production, thereby disturbing the normal arterial homeostasis between prostacyclin and thromboxane $\mathrm{A}_{2}$ and thus predisposing to atherothrombosis ${ }^{46}$; thirdly, if pulmonary megakaryocytes are the principal source of platelets then disturbance of the lung and megakaryocyte interaction (due to a change in either the pulmonary vessels and their biochemical environment or in the megakaryocyte size and protein structure) may result in dysthrombopoiesis ${ }^{27}$ and thus predispose to both respiratory and cardiovascular disease. ${ }^{28-30}$ Our results indicate an increased pulmonary megakaryocyte count in association with both respiratory disease and cardiovascular disease, especially shock and thromboembolism (both findings agree with those of previous reports ${ }^{1535}$ ), myocardial infarction, and severe atheroma.

There are two explanations for these observations. Firstly, the number of pulmonary megakaryocytes may be increased in association with respiratory disease, with resulting secondary atherothrombotic complications. It has already been shown that the efficiency of the pulmonary vascular filter can be affected by lung diseases such as bronchitis and bronchopneumonia. ${ }^{47}$ Impaired megakaryocyte fragmentation in certain respiratory disorders may yield larger fragments than usual-some of these may be retained in the lungs and appear as naked or seminaked nuclei, while others will escape into the peripheral circulation. As large platelets may be more reactive, ${ }^{4850}$ this would predispose to secondary atherothrombosis. Supporting evidence comes from reports of an increased mean platelet volume in relation to both chronic hypoxia ${ }^{30}$ and myocardial infarction. ${ }^{51-54}$ Interestingly, only $22 \%$ of the megakaryocytes that we observed in the lungs possessed copious cytoplasm, thereby suggesting that most are either released from the marrow as effete naked an seminaked nuclei, or that intact cells emobolising tō the lungs are rapidly fragmented in the pulmonary capillaries. This explanation seems unlikely, however, as the relative proportion of naked and seminaked megakaryocyte nuclei in patients with severe atheroma was not increased. A more likely association is that the number of pulmonary megakaryocytes is increased in association with atherosclerotic disease because of enhanced thrombopoiesis due to increased platelet consumption - either as a result of a genetically or environmentally acquired tendency, or both, to increased platelet-vessel wall interaction, or as a result of increased platelet adherence to ulcerated atheroma. Respiratory complications may subsequently develop as a direct consequence of the increased presence and fragmentation of megakaryocytes in the lungs, a feature already implicated in asthma, ${ }^{5566}$ pulmonary hypertension, ${ }^{57}$ the shock lung $^{36}$ and the adult respiratory distress syndrome. ${ }^{39}$ o

The higher pulmonary megakaryocyte counts found in men are consistent with a higher incidence of pulmonary and cardiovascular disease also found in $\omega$ men. The failure to show a correlation between the megakaryocyte counts before and after death, although consistent with that of previous reports, ${ }^{3536} \mathbb{\Phi}$ is not consistent with the hypothesis that the lungs are the principal site of thrombopoiesis. The pulmonary $\stackrel{0}{\supset}$ (a) $\vec{\omega}$ 严 
megakaryocyte content may be disturbed by the circulatory changes associated with death, a view supported by the fact that there is a direct relation between the circulating platelet count in life and the pulmonary megakaryocyte density; the introduction of thrombocytopenia in experimental animals increases both circulating and intrapulmonary megakaryocytes. ${ }^{4058}$ Previous reports indicate that the pulmonary megakaryocyte density is affected by both haemorrhage $^{35}$ and hypoxia. ${ }^{30}$ Our findings in relation to shock agree with this. There was no relation, however, between the megakaryocyte numbers in the lung and the haemoglobin concentration.

In contrast to the findings of previous work, ${ }^{35}$ we found no appreciable increase in the pulmonary megakaryocyte count in association with fever, infection, or neoplasia, though leucocytosis did have a positive effect. Similarly, despite increasing atheromatous disease with advancing age there was no demonstrable increase in the pulmonary megakaryocyte count. This, however, probably reflects age clustering, as most of the subjects were of late middle age (mean age $=59.2$ years, $($ SD 22.33)). Our findings suggest that, although the lungs may not be the major site of platelet production, it would be wise not to neglect the role of pulmonary megakaryocytes in thrombopoiesis, particularly in relation to cardiovascular and pulmonary diseases.

This work formed part of an intercalated BSc project, during which GS was supported by an MRC Award. We thank Mrs J Jones for secretarial help.

\section{References}

1 Tavassoli M. Review article: megakaryocyte platelet axis and the process of platelet formation and release. Blood 1980; 55:537-45.

2 Yamada E. The fine structure of the megakaryocyte in the mouse spleen. Acta Anat (Basel) 1957;29:267-90.

3 Behnike $O$. An electron microscope study of the megakaryocyte of the rat bone marrow. 1. The development of the demarcation membrane system and the platelet surface coat. J Ultrastruct Res 1968;24:412-33.

4 Wright JH. The histogenesis of the blood platelets. J Morphol 1910;21:263-78.

5 Behnike $O$. An electron microscope study of the rat megakaryocyte. 11. Some aspects of platelet release and microtubules. J Ultrastruct Res 1969;26:111-29.

6 Lichtman MA, Chamberlain JK, Simon W, Santillo PA. Parasinusoidal location of megakaryocytes in marrow: a determinant of platelet release. Am J Hematol 1978;4:303-12.

7 Radley JM, Scurfield G. The mechanism of platelet release. Blood 1980;56:996-9.

8 Becker RP, De Bruyn PPH. The transmural passage of blood cells into myeloid sinusoids and the entry of platelets into the sinusoidal circulation: a scanning electron microscope investigation. Am J Anat 1976;145:183-206.

9 Slater DN, Trowbridge EA, Martin JF. The megakaryocyte in thrombocytopenia: a microscopic study which supports the theory that platelets are produced in the pulmonary circulation. Thromb Res 1983;31:163-76.
10 Trowbridge EA, Martin JF, Slater DN. Evidence for a theory of physical fragmentation of megakaryocytes, implying that all platelets are produced in the pulmonary circulation. Thromb Res 1982;28:461-75.

11 Tavassoli M, Aoki M. Migration of entire megakaryocytes through the marrow-blood barrier. Br J Haematol 1981; 48:25-9.

12 Kinosita R, Ohno S. Biodynamics of thrombopoiesis. In: Johnson SA, Monto RW, Roebuck JW, Horn RC, eds. Blood platelets. Boston: Little, Brown, 1958.

13 Hansen $M$, Tinggaard-Pedersen N. Circulating megakaryocytes in blood from the ante-cubital vein in healthy adult humans. Scand J Haematol 1978;20:371-6.

14 Brill R, Halpern MM. The frequency of megakaryocytes in autopsy sections. Blood 1948;3:286-91.

15 Smith EB, Butcher $J$. The incidence, distribution and significance of megakaryocytes in normal and diseased human tissues. Blood 1952;7:214-24.

16 Howell WH, Donahue OD. The production of blood platelets in the lungs. $J$ Exp Med 1937;65:177-204.

17 Jordon HE. Origin and significance of the megakaryocytes of the lungs. Anat Res 1940;77:91-9.

18 Kaufman RM, Airo R, Pollack S, Crosby WH, Doberneck R. Origin of pulmonary megakaryocytes. Blood 1965;25:767-74.

19 Scheinin TM, Koivuniemi AP. Megakaryocytes in the pulmonary circulation. Blood 1963;22:82-7.

20 Melamed MR, Cliffton EE, Mercer C, Koss LG. The megakaryocyte blood count. Am J Med Sci 1966;25:301-9.

21 Tinggaard-Pedersen N. Occurrence of megakaryocytes in various vessels and their retention in the pulmonary capillaries in man. Scand J Haematol 1978;21:369-75.

22 Kallinikos-Maniatis A. Megakaryocytes and platelets in central venous and arterial blood. Acta Haematol (Basel) 1969; 42:330-5.

23 Tinggaard-Pedersen $\mathrm{N}$. The pulmonary vessels as a filter for circulating megakaryocytes in rats. Scand J Haematol 1974; 13:225-31.

24 Warheit DB, Barnhart MI. Circulating megakaryocytes and the microvasculature of the lung. Scanning Electron Microscopy 1980;111:255-62.

25 Kaufman RM, Airo R, Pollack S, Crosby WH. Circulating megakaryocytes and platelet release in the lungs. Blood 1965; 26:720-9.

26 Trowbridge EA, Martin JF, Slater DN, et al. The origin of platelet count and volume. Clin Phys Physiol Meas 1984;5:145-70.

27 Slater D, Martin J, Trowbridge A. Circulating megakaryocytes. Histopathology 1983;1:136-40.

28 Martin JF, Slater DN, Trowbridge EA. Abnormal intrapulmonary platelet production: a possible cause of vascular and lung disease. Lancet 1983;i:793-6.

29 Slater DN, Martin JF, Trowbridge EA. The lung: a platelet factory and megakaryocyte graveyard in health and disease. $J$ Pathol 1983;140:144.

30 Metcalfe B, Warren C, Slater D, Trowbridge A, Martin JF, Barer GR. Changes in platelets and megakaryocytes in simulated high altitude in rats. Clin Sci 1984;67 (suppl 9):76.

31 Crocker J, Smith PJ. Value of factor VIII related antigen as a means of demonstrating extramedullary megakaryocytopoiesis. J Clin Pathol 1984;37:843-5.

32 Hoyer LW, de los Santos RP, Hoyer JR. Anti-haemophilic factor antigen: localisation in endothelial cells by immunofluorescent microscopy. J Clin Invest 1973;52:2737-44.

33 Piovella F, Nalli G, Molamani GD, et al. Demonstration by electron microscopy of the subcellular localisation of factor VIIIrelated antigen in human platelets and megakaryocytes. In: Neri Serneri GG, Prentice CRM, eds. Haemostasis and thrombosis. London: Academic Press, 1979.

34 McGill HC, Brown BW, Gore I, et al. Report of committee on grading lesions. Council on arteriosclerosis. American Heart Association: grading human atherosclerotic lesions using a 
panel of photographs. Circulation 1968;37:455-9.

35 Aabo K, Bendix-Hansen K. Megakaryocytes in pulmonary blood vessels. 1 Incidence at necropsy, clinicopathological relations, especially to disseminated intravascular coagulation. Acta Pathol Microbiol Scand 1978;86:285-91.

36 Wells S, Sissons M, Hasleton PS. Quantitation of pulmonary megakaryocytes and fibrin thrombi in patients dying from burns. Histopathology 1984;8:517-27.

37 Sharnoff JG, Kim ES. Evaluation of pulmonary megakaryocytes. JAMA 1958;66:176-82.

38 Sharnoff JG. Increased pulmonary megakaryocytes: probable role in post-operative thromboembolism, JAMA 1959;1: 108-11, 688-91.

39 Hasleton PS. Adult respiratory distress syndrome-a review. Histopathology 1983;7:307-32.

40 Bendix-Hansen K, Aabo K, Myhre-Jensen O. Response of pulmonary (circulating) megakaryocytes to experimentally induced consumption coagulopathy in rabbits. Acta Pathol Microbiol Scand 1979;87:165-72.

41 Bendix-Hanson K, Aabo K. Distribution of intrapulmonary megakaryocytes. Acta Pathol Microbiol Scand (A) 1981;89:169-71.

42 Davies $D$. Deaths from coronary artery disease and coal-worker's pneumoconiosis. Br Med J 1976;ii:925-7.

43 Mitchell RS, Silvers GW, Dart GA, et al. Clinico-morphological complications in chronic airways obstruction. Am Rev Respir Dis 1968;97:54-62.

44 Friedman GD, Klatsky AL, Siegelaub AB. Lung function and risk of myocardial infarction and sudden cardiac death. New Engl J Med 1976;294:1071-5.

45 Stender S, Astrup P, Kjedlsen K. Hyperoxia-induced decrease in aortic accumulation of cholesterol in rabbits previously fed a cholesterol rich diet. Exp Mol Pathol 1976;25:221-6.

46 Gryglewski RJ, Korbut R, Ocetkiewicz A. Generation of prostacyclin by lungs in vivo and its release into the arterial circulation. Nature 1978;273:765-7.

47 Hansen M, Tinggaard-Pedersen N. Circulating megakaryocytes in patients with pulmonary inflammation and in patients subjected to cholecystectomy. Scand J Haematol 1979;23:211-16.
48 Garg SK, Amorosi EL, Karpatkin S. Use of the megathrombocyte as an index of megarkaryocyte number. New Engl J Med 1971;284;11-17.

49 Mannucci PM, Sharp AA. Platelet volume and shape in relation to aggregation and adhesion. Br J Haematol 1967;13:604-17.

50 Eldor A, Avitzour M, Or R, Hanna R, Pencas S. Prediction of haemorrhagic diathesis in thrombocytopaenia by mean platelet volume. Br Med J 1982;285:397-400.

51 Cameron HA, Phillips R, Ibbotson RM, Carson PHM. Platelet size in myocardial infarction. $\mathrm{Br}$ Med $J$ 1983;287:449-51.

52 Martin JF, Plumb J, Kilbey RS, Kishk YT. Changes in volume and density of platelets in myocardial infarction. $\mathrm{Br} \mathrm{Med} \mathrm{J}$ 1983;287:456-9.

53 Sewell R, Ibbotson RM, Phillips R, Carson P. High mean platelet volume after myocardial infarction: is it due to consumption of small platelets? Br Med J 1984;289;1576-8.

54 Trowbridge A, Slater D, Kishk Y, Martin J. High mean platelet volume after myocardial infarction. Br Med $J$ 1985;290:238.

55 Morley J, Sanjar S, Page CP. The platelet in asthma. Lancet 1984;ii:1142-4.

56 Slater D, Martin J, Trowbridge A. The platelet in asthma. Lancet 1985; i:110.

57 Rubin LJ, Lazar JD. Influence of prostaglandin synthesis inhibitors on pulmonary vaso-dilatory effects of hydralazine in dogs with hypoxic pulmonary vaso-constriction. $J$ Clin Invest 1981;67:193-200.

58 Warheit DB, Barnhart MI. Megakaryocytes in the lung after thrombin initiated diffuse microthrombosis: a preliminary report on ultrastructure. Scanning Electron Microscopy. 1979;111:801-8.

Requests for reprints to: Dr IC Talbot, Department of Pathology, Clinical Sciences Building, Leicester Roya $\overline{6}$ Infirmary, PO Box 65, Leicester LE2 7LX, England. 